\title{
Siltation rate and main anthropic impacts on sedimentation of the São Luís tidal inlet - State of Maranhão, Brazil
}

\author{
James Werllen de Jesus Azevedo ${ }^{1 *}$, Antonio Carlos Leal de Castro ${ }^{l}$, \\ Marcio Costa Fernandes Vaz dos Santos ${ }^{1}$
}

\author{
${ }^{1}$ Universidade Federal do Maranhão. \\ (Av. dos Portugueses, 1966; Bacanga - CEP 65080-805; São Luís - MA) \\ *Corresponding author: jameswerllen@yahoo.com.br
}

\begin{abstract}
In recent decades, intense human intervention in the coastal zone has given rise to severe siltation and erosion problems. This scenario is located the São Luís tidal inlet, formed by the mouths of the Anil and Bacanga rivers which due to various kinds of interference have been changing their sediment transport and deposition processes. With these changes in mind, this study sought to evaluate the evolution of the siltation and sedimentation rates in this area, as well as the main anthropogenic influences associated with this process. The methodology consisted in verifying the morphological evolution on the basis of the scanning and vectorization of nautical charts of 1947 and 1966, bathymetric surveys conducted in 2006, and aerial photos dating from 2011. The results show a silting up process coincident with interventions that occurred in the Anil and Bacanga river basins, with a volume of silt estimated at $8.5 \times 106 \mathrm{~m}^{3}$, over the period from 1944 to 2011 (64 years), at a rate of $1.6 \mathrm{~cm} \cdot \mathrm{yr}^{-1}$. These processes are associated mainly with the construction of the Bacanga dam and land reclamation projects undertaken for the purpose of providing new areas for urban expansion. The evaluation of the results showed intense and advanced silting up of the São Luís tidal inlet, at rates proportionally greater than those of other estuaries, calling for corrective actions and the implementation of coastal management policies for this area.
\end{abstract}

Descriptors: Coastal zone, Nautical charts, Bathymetry, Dam, Sedimentary filling.

\section{Resumo}

As intensas intervenções antrópicas na zona costeira fizeram surgir, nas últimas décadas, graves problemas de assoreamento e erosão nessas áreas. Neste cenário, enquadra-se a embocadura estuarina de São Luís, formada pela foz dos rios Anil e Bacanga, que devido a diversas interferências, vem sofrendo alterações nos processos de transporte e deposição. Em função de tais alterações, realizou-se o presente estudo que objetivou avaliar a evolução e estimar as taxas de assoreamento na referida área, assim como verificar as principais influências antrópicas associadas ao processo. Analisou-se a evolução morfológica a partir da digitalização e vetorização das cartas náuticas de 1947 e 1966, levantamentos batimétricos realizados em 2006, e fotos aéreas datadas de 2011. Os resultados evidenciaram um processo de preenchimento sedimentar que coincide com as intervenções que ocorreram na bacia dos rios Anil e Bacanga, com estimativas de volume assoreado na ordem de 8,5x106 $\mathrm{m}^{3}$, no período de 1944 a 2011 (64 anos), com taxa de $1,6 \mathrm{~cm} \mathrm{ano}^{-1}$. Esses processos estiveram associados principalmente à construção da barragem do Bacanga e atividades de aterramento para construção de avenidas e expansão de bairros. A avaliação dos resultados demonstra intenso e avançado processo de preenchimento sedimentar na região da Embocadura Estuarina de São Luís, inclusive com taxas proporcionais superiores às registradas em outros estuários semelhantes do planeta, impondo a necessidade de ações corretivas e aplicação de políticas de gestão costeira para a área.

Descritores: Zona costeira, Cartas náuticas, Batimetria, Barragem, Preenchimento sedimentar. 


\section{INTRODUCTION}

Coastal evolution is the product of morphodynamic processes that occur in response to changes in external conditions (WRIGHT; THOM, 1977). Coastal dynamics impact not only shoreline physiography, but also sediment deposit properties through the sorting of grain size, density, shape and nature. The overall effect will determine sediment transport and erosion and deposition patterns within the coastal system (ALBINO et al., 2001).

Although coastal environments and associated deposits are extremely diverse, sedimentological models promote the notion that coastal deposits can be identified as wave or tide dominated based upon their sedimentary character (BOYD et al., 1992). In fact, wave and tide dominated settings are distinctive in terms of physical processes and geomorphology, which cause these two settings to develop distinctive sedimentary deposits.

WOODROFFE (2007) has made it clear that coastal zones are particularly dynamic and their morphology is continually changing in response to various processes operating at different rates. Coastal landforms are extremely changeable and coastal habitats change over a range of spatial and temporal scales and recognition of these variations is necessary for effective planning and management.

Regarding the scales, COWELL and THOM (1997) emphasize that the morphodynamic processes operate within a broad bandwidth of spatial and temporal scales, in which 'engineering time scales' are understood to cover periods of a few months to decades and 'macro spatial scales' of some tens to hundreds of kilometers.

An understanding of the dynamic coastal system is crucial to evaluate current states and estimate future development under natural forcing and direct and indirect anthropogenic influence. In this regard, the increasing realization that human impacts are affecting our coastlines, estuaries and bays is noteworthy, having been highlighted in several studies (MADRUGA FILHO, 2004; FAN et al., 2006; JAFFE et al., 2007; ARAÚJO et al., 2007; SHI et al., 2011).

SOUZA (2009) also highlights the fact that human occupation on the coast has led to intensive siltation and erosion problems in estuary environments, especially in recent decades, leading to an imbalance in the coastal zone in virtually all the countries that border the ocean. The economic repercussions of this process, such as the loss of public infrastructure or private property, can be extremely serious, especially in developing countries, due to the lack of resources for the recovery of such properties and the harm caused to the environment.

Many estuaries in Brazil are currently undergoing an evident process of siltation (FRAGOSO JÚNIOR et al., 2008). This scenario is to be seen the São Luís tidal inlet in the capital city of the state of Maranhão (northeastern Brazil), which is located on São Marcos Bay. Over time, the siltation process in the tidal inlet could compromise the navigability of the mouths of the Anil and Bacanga rivers with a negative impact on tourism, aquatic sports, fishing activities and water quality. Although knowledge of longterm trends in deposition and erosion are important for proper management of estuarine ecosystems, it is difficult to gain this knowledge from short field experiments or other traditional methods. A long-term, large scale perspective of the sediment system is possible, however, by analyzing a long sequence of bathymetric surveys.

Thus, the aim of the present study was to investigate the evolution and sedimentation rates in the São Luís tidal inlet (based on 64 years of analysis), as well as the main anthropogenic influences that favored the development of this process in the region in such a way as to allow the establishment of public policies directed at the management of this process in this tidal inlet as well as similar locations throughout Brazil.

\section{MATERIAL AND METHODS}

São Luís Island $\left(02^{\circ} 24^{\prime} 09^{\prime \prime}\right.$ to $02^{\circ} 46^{\prime} 13^{\prime \prime} \mathrm{S}$ and $44^{\circ} 01^{\prime} 20^{\prime \prime}$ to $44^{\circ} 29^{\prime} 47^{\prime \prime}$ W) is bordered by the São Marcos Bay to the west, São José Bay to the east, Mosquito Straights to the south and the Atlantic Ocean to the north. Four municipalities are located on the island: São Luís, São José de Ribamar, Paço do Lumiar and Raposa. The study area (São Luís tidal inlet) is located in the city of São Luís and extends from Guia Point to Areia Point, encompassing the mouths of the Bacanga and Anil rivers on the eastern coast of São Marcos Bay. The area selected for the analysis of siltation dynamics is bounded by Areia Point to the north, the Bacanga dam to the south and Bonfim Point to the west (Figure 1). The choice of this area was based on the availability of bathymetric data for the time period selected and to the fact that it is the area in the tidal inlet where the siltation process is most accentuated.

The geomorphological structuring addressed in the present study was investigated to determine the deposition 


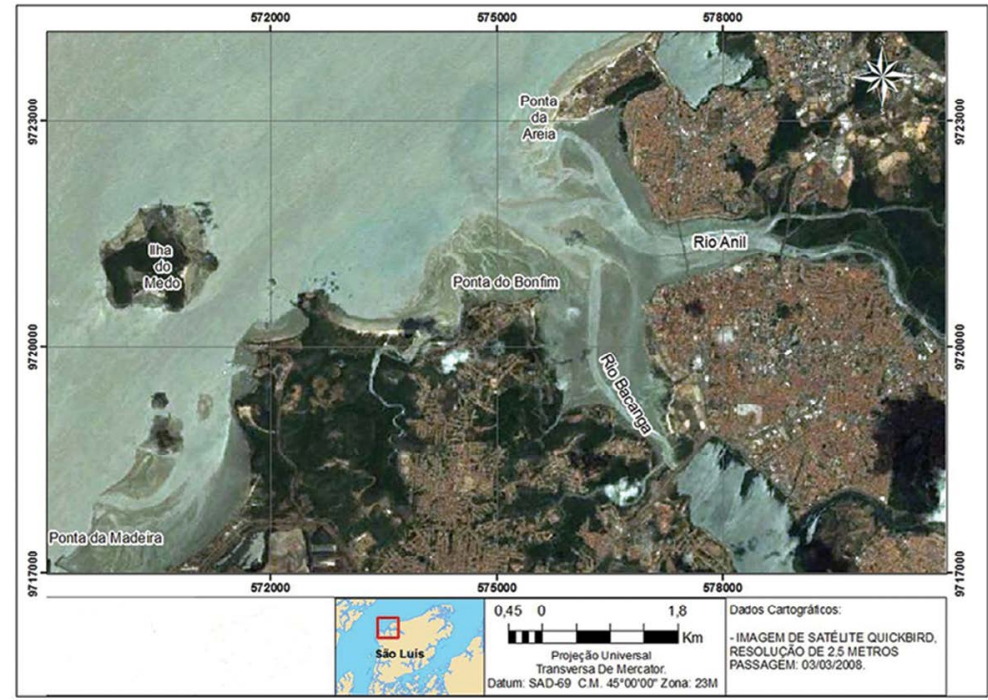

Figure 1. Map of study area.

patterns in the access channel to the Port of São Luís (tidal inlet). The procedure consisted of designing a conceptual model based on an analysis of nautical charts of the Brazilian Navy's Hydrography and Navigation Board (DHN) from the years 1947 and 1966, as well as bathymetric surveys conducted by VALE in 2006 (Figure 2), focused on the Study of the Environmental Impact for Implementation of Coastal Water Containment and Dredging of the São Luís Harbor Navigation Channel, and aerial images taken at different tidal levels during the year 2011.

Due to the large tidal range found in the study area, the effects of meteorological tides are proportionally small, and can therefore be neglected in this evaluation.
Thus, tide gauge data of São Luís (formerly the Port of São Luís), located at the UTM coordinates E576751, N9720412 SAD69, were used to make bathymetric corrections and indicate the dimension of the tide for different images of 2011. These data refer to its constituent or harmonic components. Through harmonic constituents, using numerical formulas, the tide levels at each of the locations can be predicted. These constituents were obtained from the harmonic analysis of tidal measurement data developed by the Marine Studies Foundation of Brazil (FEMAR).

The nautical charts were scanned and georeferenced by the Universal Transverse Mercator System (horizontal

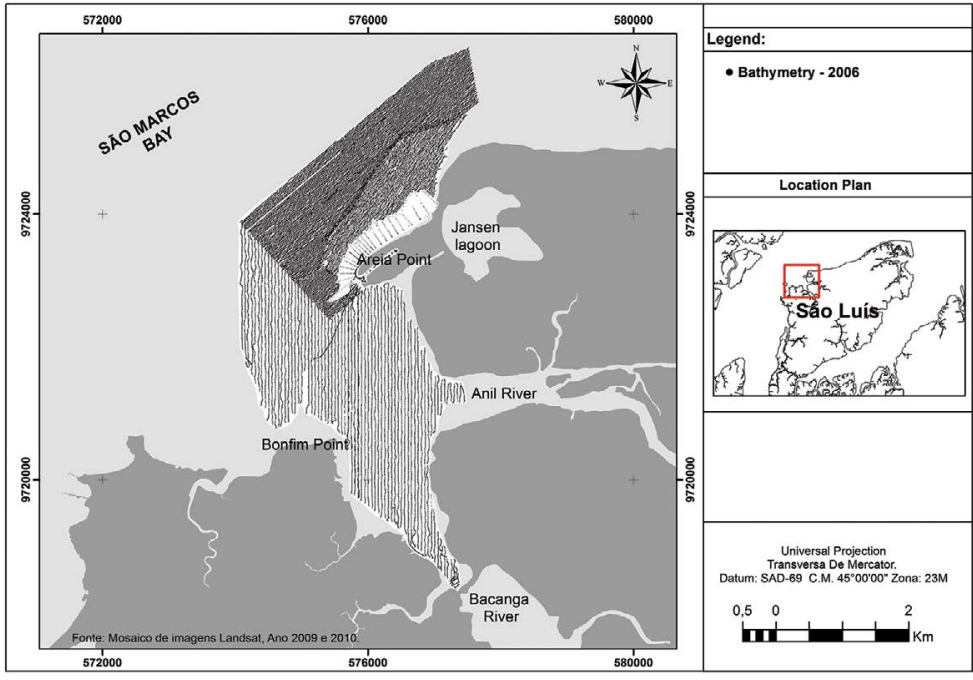

Figure 2. Bathymetric profiles at the São Luís tidal inlet and adjacent coastal areas surveyed by VALE in 2006. 
datum SAD69). The isobaths and limits of sandbanks and mud were vectored and the resulting digitized lines were converted into files with altimetric points, and in the sequence into an elevation 3D grid, which was used to calculate siltation and erosion volumes. The 2011 aerial photos do not have elevation data, therefore the water level in photos, taken at different time on the same day, was taken as a reference datum, using the predicted water level from the tide table. The altimetry vectoring of the georeferenced raster images was performed using the Geographic Information System (GIS) software SPRING 5.0.

The original objective of DHN charts was to provide reliable mapping of navigation channels (restricted area of the tidal inlet) and therefore, the charts do not detail altimetric data of sandbanks. Thus, a specific method was adopted to enrich the digital model of the terrain, which consisted of the altimetric georeferencing of the limits of notable features, such as the mangrove forest and plains of adjacent mud banks (mudflats), as well as the maximum and minimum limits of spring tides (Table 1).

The evolution of silted volume in the study area was obtained from the data processing software SURFER 10 (Golden Software), by the interpolation method called Natural Neighbor. This interpolation method was used because it presented a good overall accuracy and a better fidelity to the original data when compared to other methods. The density of points used for the interpolation was $3,703,3,281,69,052$ and 37,147 for the years 1947 , 1966, 2006 and 2011, respectively.
The estimated siltation volume was defined based on the arithmetic mean of Simpson's method, Simpson's $3 / 8$ method and the trapezoidal rule (ODRESKI et al., 2003). The SURFER 10 tool known as Blank, was used to define similar intervals among different bathymetric maps, thus minimizing possible errors during volume and embankment calculations. The same procedure was applied in the comparison of different period Digital Elevation Models (DEM), in order to evaluate spatial and temporal patterns of the erosion and sedimentation processes.

Thus, the region depicted for the preparation of volume calculations included the limits established by Areia Point, to the north, Bacanga dam, to the south, and Bonfim Point, to the west, constituting a total area of $8.5 \mathrm{~km}^{2}$.

The reduction of water surface acreage of the São Luis tidal inlet between 1966 and 2011 was also employed as an indicator of the predominant siltation process. The evaluation of the acreage changes was performed with the software SPRING 5.0.

\section{RESULTS}

Bathymetric information collected for 1947 and 1966 demonstrates stable conditions in the São Luís tidal inlet. During this period, no dredging works, dune fixation or any human interference with a potential to change the sediment balance in the region was observed. This setting indicates the presence of a single main channel, maintained by flood and ebb currents, coming from the Bacanga river, joining

Table 1. Approximate elevation of landscape features in the region between tides used to complete the digital terrain model of the estuaries of the Anil and Bacanga rivers. The IBGE elevation refers to the Imbituba national elevation datum of the Brazilian Institute of Geography (IBGE).

\begin{tabular}{|c|c|c|c|}
\hline LIMIT & DHN elevation (meters) & IBGE elevation (meters) & DESCRIPTION \\
\hline Lower limit of mudflat & 1.56 & -1.0 & $\begin{array}{l}\text { The mudflat is the region between tide levels } \\
\text { that is only exposed every two weeks during } \\
\text { the new and full moons and is technically } \\
\text { equivalent to the mean low spring tide. It } \\
\text { is without mangrove vegetation due to the } \\
\text { excessive time spent submerged }\end{array}$ \\
\hline $\begin{array}{l}\text { Colonization of mudflat by } \\
\text { isolated individuals ( } 4 \text { to } 5 \mathrm{~m} \\
\text { high) of Laguncularia racemosa }\end{array}$ & 2.56 & 0.0 & $\begin{array}{c}\text { Laguncularia racemosa (white mangrove) } \\
\text { is a primary colonizer in mudflats more } \\
\text { exposed to tidal currents }\end{array}$ \\
\hline $\begin{array}{l}\text { Lower limit of developed } \\
\text { mangrove forest }\end{array}$ & 4.26 & 1.70 & Characteristic bands of mangrove vegetation \\
\hline $\begin{array}{l}\text { Lower limit of mangrove tree } \\
\text { canopy }\end{array}$ & 5.26 & 2.70 & $\begin{array}{l}\text { The mean tide level causes the systematic } \\
\text { "pruning" of the lower portion of the canopy }\end{array}$ \\
\hline $\begin{array}{l}\text { Maximum limit of high spring } \\
\text { tide }\end{array}$ & 6.56 & 4.00 & $\begin{array}{l}\text { The limit of tidal region of terra firma, easily } \\
\text { identified in aerial photos by the contrast be- } \\
\text { tween the mangrove vegetation and terra firma }\end{array}$ \\
\hline
\end{tabular}


the channel of the Anil river (Figures 3A and 3B). Along the main channel, depths of up to $11.0 \mathrm{~m}$ were observed in this period, and also a volume estimated at $5.0 \times 10^{6} \mathrm{~m}^{3}$ for areas below the elevation of $0.0 \mathrm{~m} \mathrm{DHN}$, which are areas always submerged in the low tides of syzygy.

Bathymetric surveys undertaken in 2006 defined drastic geomorphological changes in the study area. The presence of two different channels with access to the bay can be observed in low tide conditions (Figure 3C), with depths that prevent navigation at any point in the tidal cycle. The results indicate volumes of approximately $110,000 \mathrm{~m}^{3}$ for areas below $0.0 \mathrm{~m} \mathrm{DHN}$.

Analyses undertaken in 2011 presented a geomorphological configuration of the study area, similar to that observed in 2006 (Figure 3D), but with changes mainly in 4.0 and 6.5 $\mathrm{m}$ DHN elevation class. In this altimetric interval, a loss of water volume around $4.8 \times 10^{6} \mathrm{~m}^{3}$ was estimated, while in the lower levels the results presented were very close to these. These results show the dynamics of the siltation process in the area investigated, with depositions located initially on the lower levels. In sequence, these depositions achieved the highest levels. It is noteworthy that both in 2006 and in 2011 , maximum depths $(3.0 \mathrm{~m})$ were observed along the channel.

The changes in this 64-year period were also observed through two bathymetric profiles in the region (Figure 4), framing the area of the mouth (A and A') and a segment near the mouth of Anil river (B and B').

The profile analysis in the São Luís tidal inlet (A and A') signals a significant siltation in the region, with maximum depths reduced from $6.0 \mathrm{~m}$ to near $0.0 \mathrm{~m}$ between 1947 and 2011. The morphology indicates the presence of a deep channel on the right bank in the period from 1947 to 1966. However, considering the analyses of 2006 and 2011, there was a pronounced sedimentary fill in the area, which made the presence of another channel on the left bank more evident. However, both had little substantial depths if compared to previous morphological conditions.

The profile made at the mouth of Anil river (B and B') also indicated a sedimentary filling process and the maintenance of the channel on the right bank was observed. Noteworthy is the significant morphological change on the left bank of the mouth of the Anil river, also in the period from 2006 to 2011 (a period of only 5 years).

The analysis of the spatial and temporal dynamics of erosion and deposition processes in the São Luis tidal inlet employed the bathymetry differences observed in the 1947 to 2006 period (Figure 5). Between 1947 and 1966 there was localized deposition of up to $+2 \mathrm{~m}$. However, the erosion was predominant, especially in the main channel area, with bottom depth reduction of up to $-4 \mathrm{~m}$. In the same period the average depth of the Sao Luis tidal inlet increased from 3.03 to $3.70 \mathrm{~m}$.

The largest sedimentation rates were observed between 1966 and 2006, and were spread over the whole main channel. Deltas formed from tidal currents on flooding tides also developed in this period.

The depositional sequence can be summarized as beginning with the filling up of the deeper areas, with a gradual expansion into the higher elevation sites between 0 and $6.5 \mathrm{~m} \mathrm{DHN}$.

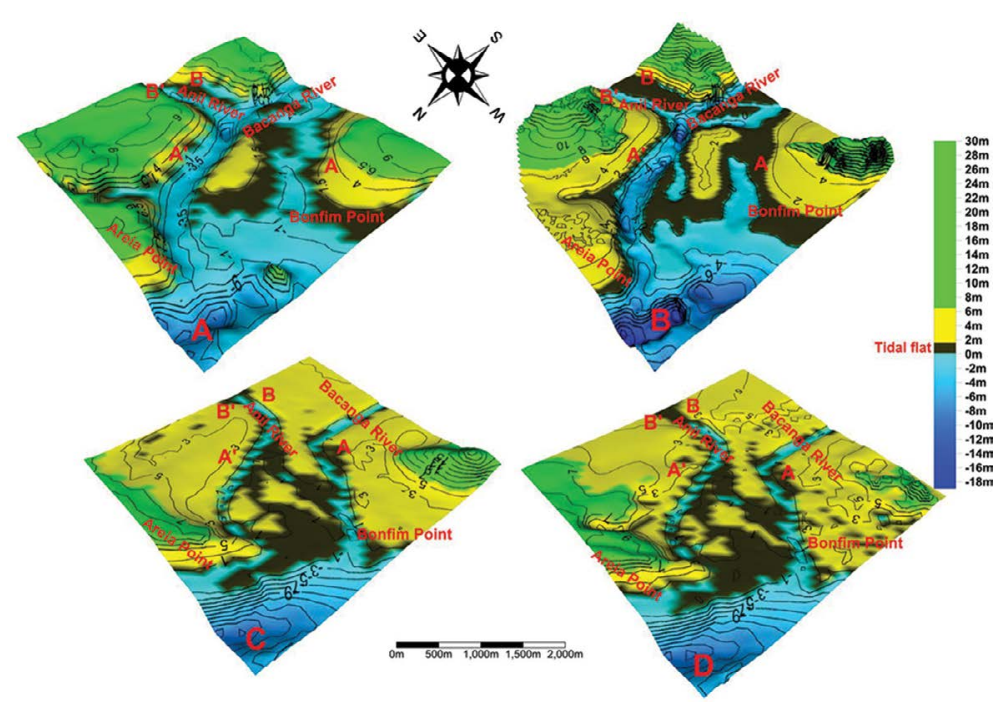

Figure 3. Bathymetry maps of São Luís tidal inlet, in the period 1947 (A), 1966 (B), 2006 (C) and 2011 (D). A - A' and B - B' indicate the bathymetric profile in the area. 

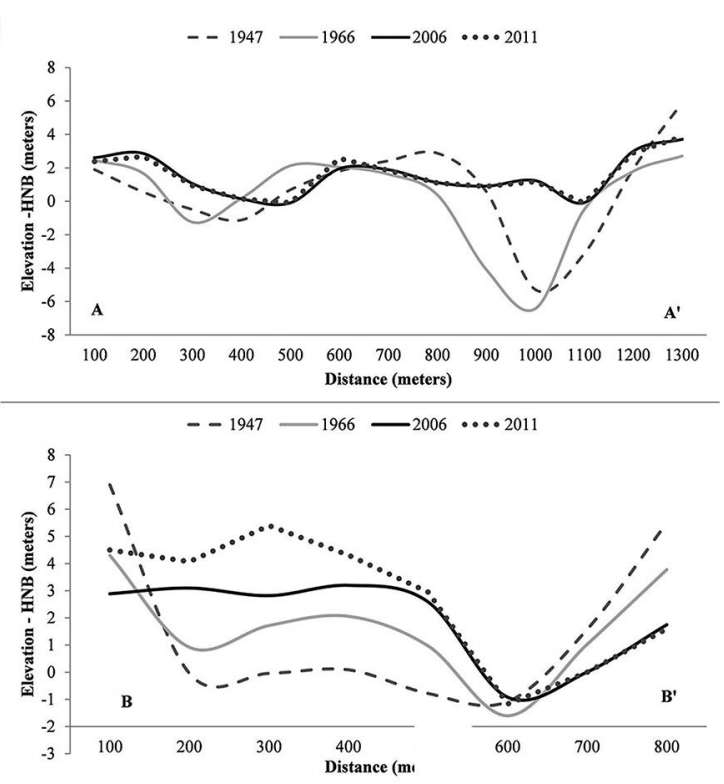

Figure 4. Bathymetric profile in the São Luís tidal inlet (A and $\left.\mathrm{A}^{\prime}\right)$ and for the estuary of the Anil river (B and B') in the years 1947, 1966, 2006 and 2011.

The predominance of deposition over erosion observed in the 1966 to 2006 period, can be correlated with several anthropic interventions on the sedimentation balance of the Sao Luis tidal inlet, such as the construction of the Bacanga dam in 1970 and several other land reclamation projects associated with urban expansion.

The human interventions on the tidal inlet increased the sediment deposition rate, which in turn would reduce the tidal prism volume (and associated tidal currents), and further accelerate the deposition of sediments.

In the period between 2006 and 2011 the deposition and erosion processes were less intense in the lower elevations, as evidenced by the occurrence of no change areas in Figure 5. However, at higher elevations in the intertidal zone deposition greater than $2 \mathrm{~m}$ was observed.

The evaluation of the results based on the geomorphological evolution of the area from 1947 to over 11 signals a significant loss in water volume, which would occupy the space between the maximum high tide (6.5 m DHN) and the bottom of an area of approximately $8.5 \mathrm{~km}^{2}$, including the mouths of the Anil and Bacanga rivers. Estimates indicated a decrease from $35.7 \times 10^{6} \mathrm{~m}^{3}$ in 1947 to $27.2 \times 10^{6} \mathrm{~m}^{3}$ in 2011 , approximately $24 \%$ of the loss of water volume over a 64-year period (Table 2).

Table 2. Water volumes below $6.5 \mathrm{~m}$ DHN elevation $(4 \mathrm{~m}$ IBGE), which represents the maximum high tide limit in the São Luís tidal inlet.

\begin{tabular}{ccc}
\hline & \multicolumn{2}{c}{ VOLUME } \\
YEAR & $\begin{array}{c}\text { Below maximum high } \\
\text { tide elevation }\left(106 \mathrm{~m}^{3}\right)\end{array}$ & $\begin{array}{c}\text { Below lowest mangrove } \\
\text { elevation limit }\left(106 \mathrm{~m}^{3}\right)\end{array}$ \\
\hline 1947 & 35.7 & 22.7 \\
1966 & 33.9 & 20.0 \\
2006 & 29.4 & 13.1 \\
2011 & 27.2 & 12.3 \\
\hline
\end{tabular}

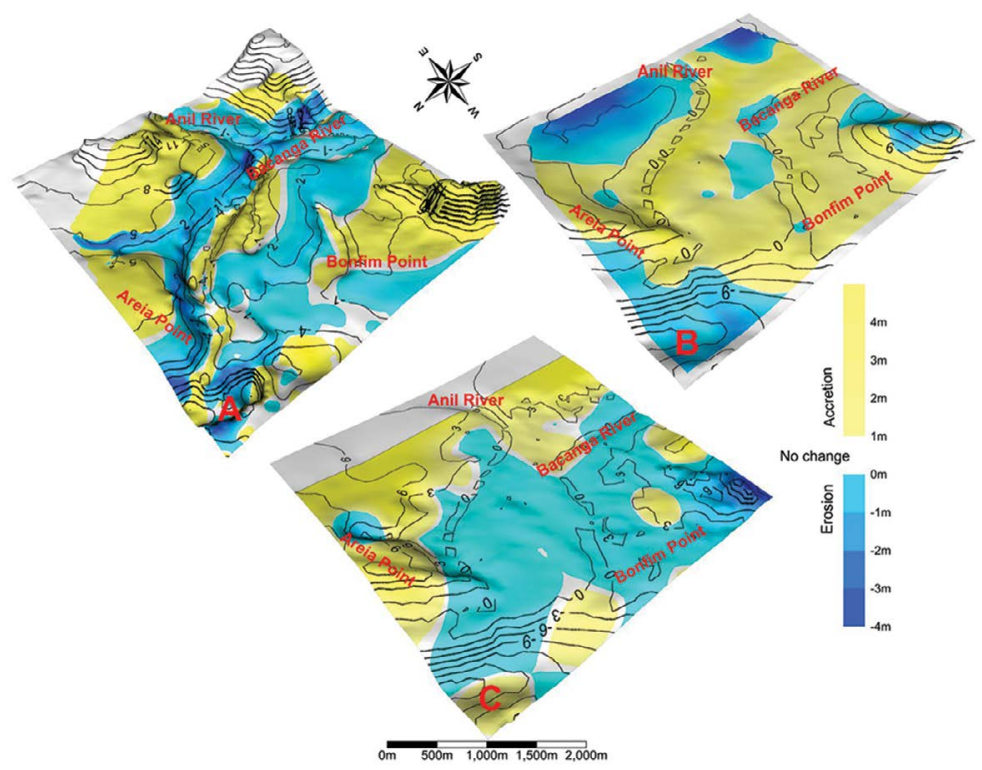

Figure 5. Synthesis of the siltation and erosion processes at the Sao Luis Tidal inlet from 1947 to 2011. (A) Period from 1947 to 1966 with 1966 isobaths superimposed. (B) Period from 1966 to 2006 with 2006 isobaths superimposed. (C) Period from 2006 to 2011 with 2011 isobaths superimposed. 
The analysis of the lower limit of the mangrove forest (4.4 m DHN) indicated a loss of $46 \%$ of water volume in the study area, with values changing from $22.7 \times 10^{6} \mathrm{~m}^{3}$ to $12.3 \times 10^{6} \mathrm{~m}^{3}$ between 1947 and 2011, respectively.

Anthropic interventions, represented by dam construction, mangrove loss and land reclamation projects, were the main cause behind the tidal prism reduction in the estuarine portions of the Anil and Bacanga rivers.

Figure 6 shows the extension of acreage reduction of intertidal areas contributing to the daily tidal prism in the estuaries of the Anil and Bacanga Rivers, either by dam construction or land reclamation of mangrove forests. The areas lost between 1966 and 2011 are shown in red. The remaining contribution areas are shown in light (Bacanga estuary) and dark (Anil estuary) blue colors.

The original intertidal zone area was estimated at $40.6 \mathrm{~km}^{2}$ in 1966. In 2011 the total remaining area was of $13.23 \mathrm{~km}^{2}$, with $9.11 \mathrm{~km}^{2}$ and $4.12 \mathrm{~km}^{2}$ on the Anil and Bacanga rivers, respectively. The total loss of intertidal area between 1966 and 2011 was $23.36 \mathrm{~km}^{2}$.

Estimates of silted and eroded volume for the 64-year period in the São Luís tidal inlet are around $13.0 \times 10^{6}$ $\mathrm{m}^{3}$ and $4.5 \times 10^{6} \mathrm{~m}^{3}$, respectively. This resulted in a sedimentary filling process of approximately $8.5 \times 10 \mathrm{~m}^{3}$ (Table 3).

The assessment signals the intensification of the process over 64 years of analysis, a silted volume estimated at $2.7 \times 10^{6} \mathrm{~m}^{3}$ being observed, for example, between 1947 and 1966 (a 19-year interval), while in only 5 years, considering the period 2006-2011, the silted volume was $2.5 \times 10^{6} \mathrm{~m}^{3}$, the process being concentrated at higher elevations. Dividing the total silted volume by the area covered by the surveys $\left(8.5 \mathrm{~km}^{2}\right)$, the result is a value that can also be expressed as $1.0 \mathrm{~m}$, which corresponds to the thickness of the sedimentary deposit (assuming a uniform deposition across the area). The division of the thickness of the sedimentary deposit by the time elapsed (1947-2011) indicated a sedimentation rate in the São Luís tidal inlet of $1.6 \mathrm{~cm}_{\text {.year-1 }}$.

\section{DISCUSSION}

The analysis of the silting process in the São Luís tidal inlet brings to light an evolution that occurred initially in the channel sections (never exposed at low tide) that subsequently affected the intertidal zone. This information becomes important as it describes a sedimentary filling process which was initially perceived only by those who sailed the channels but which went unnoticed by others who observed only the morphological patterns on sandbanks exposed during low tide.

CARVALHO et al. (2000) stated that, in reservoirs that go through a sedimentary filling process, the visible siltation is usually the smallest portion of the deposit.

The data analyzed by the evaluation of nautical charts, bathymetry and aerial images showed that it was from the 1960s that an imbalance in the sedimentary balance in the São Luís tidal inlet began to occur, also affecting neighboring regions such as Areia Point beach, which

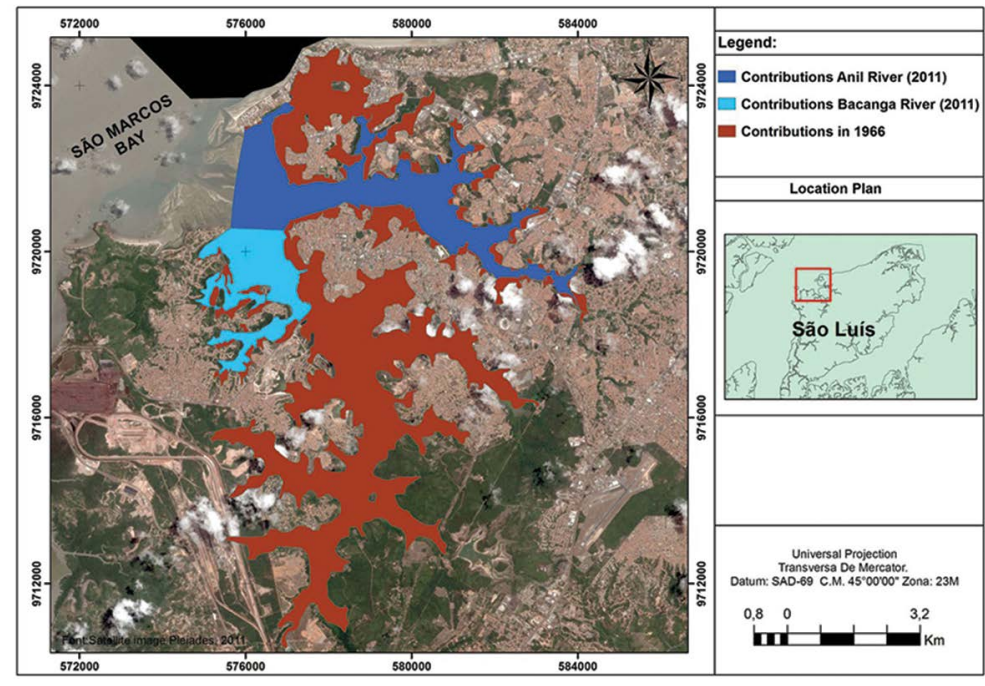

Figure 6. Reduction of the estuarine water body acreage contributing to the original tidal prism at the estuary of Bacanga and Anil Rivers, for the period between 1966 and 2011. 
Table 3. Estimates of silted and eroded sediment volumes for the study area.

\begin{tabular}{lcccc}
\hline Periods & Interval (years) & Volume silted $\left(\mathrm{m}^{3}\right)$ & Volume eroded $\left(\mathrm{m}^{3}\right)$ & Silted - Eroded $\left(\mathrm{m}^{3}\right)$ \\
\hline $1947-1966$ & 19 & $2.7 \times 10^{6}$ & $1.0 \times 10^{6}$ & $1.7 \times 10^{6}$ \\
$1966-2006$ & 40 & $7.8 \times 10^{6}$ & $3.3 \times 10^{6}$ & $4.5 \times 10^{6}$ \\
$2006-2011$ & 5 & $2.5 \times 10^{6}$ & $0.27 \times 10^{6}$ & $2.2 \times 10^{6}$ \\
$1947-2011$ & 64 & $13.0 \times 10^{6}$ & $4.5 \times 10^{6}$ & $8.5 \times 10^{6}$ \\
\hline
\end{tabular}

had its coastal processes modified by it. This imbalance coincided with certain interventions that have become common and of constant effect in the Anil and Bacanga river basins, such as the construction of the Bacanga dam, land reclamation projects for the construction of roads and the expansion of neighborhoods, such as the Bacanga urban park located near the historic center of São Luís.

According to LIMA (2007), interruptions in the outflow of rivers alter circulation and sedimentation patterns in their estuaries, leading to a deficit of sediments in the coastal zone, greater saline intrusion, spatial reorganization of the different ecological zones and the growth of sandbars. The authors state that the closure of inlets due to the growth of sandbars has been occurring frequently along the coast of the state of Bahia (Brazil), causing a reduction in the critical section of estuaries (reduction in the inlet) and possibly the loss of fluvial competence.

A barrier has also been created in the São Luís tidal inlet caused by the string of sandbanks at Areia Point, which has advanced 400 meters toward Bonfim Point in the past 30 years. The depositing of sand by the action of waves and conditions that are unfavorable to the free flow of the tide has made the bed of the channel increasingly shallow.

WRIGHT and SCHOELLHAMER (2004) also highlighted anthropic activities as primarily responsible for the change in the sediment balance of the Sacramento River, California. JAFFE et al. (2007) highlighted activities such as urbanization, agriculture and cattle grazing as major contributors to the increased sediment load in San Pablo Bay.

The result of the silting process over 64 years was estimated at $8.5 \times 10^{6} \mathrm{~m}^{3}$, which represents, considering the area and the period investigated, a sedimentary filling process of around $1.6 \mathrm{~cm}$.year ${ }^{-1}$. Following this same line of argument, ODRESKI et al. (2003) found higher values in Antonina Bay ( $2.6 \mathrm{~cm}$.year $\left.{ }^{-1}\right)$ - an area of $25 \mathrm{~km}^{2}$ - from the analysis of a period of 74 years.

SAITO et al. (2001) reported values of up to 0.98 $\mathrm{cm}$ year $^{-1}$ for the sedimentation rate in the estuarine system of Cananéia-Iguape, a value smaller than that obtained in this study. In the Santos estuary, FIGUEIRA et al. (2004) estimated values ranging from 0.16 to $0.54 \mathrm{~cm}_{\text {year }}{ }^{-1}$. In the Guanabara Bay, sedimentation rates of $0.89 \mathrm{~cm}$ year-1 were observed (OLIVEIRA et al., 2004). MARTÍNEZ et al. (2011), estimated rates of approximately $0.60 \mathrm{~cm}_{\text {.year }}{ }^{-1}$ in studies conducted in San Simón Bay.

The higher values obtained in the São Luís tidal inlet, when compared to those recorded in the literature, demonstrate how intense sedimentation processes are in the region, calling for corrective actions that will allow the maintenance of the main channel besides the monitoring of a continuous area.

It is noteworthy that the anthropic activities that once interfered in the area of basins have been stabilized in recent years, especially those related to land use and occupation. Thus, practically no contributions are assumed for the current period regarding sediment input coming from the drainage basin, meaning that current contributions derive mainly from longshore and transportation by flood tidal currents of sediment input into the study area, promoting deposition since there has been a dramatic decrease in the flow of the Anil and Bacanga rivers in recent decades, altering the sediment balance in the sector investigated.

In Chesapeake Bay (east coast of the United States), the sedimentation rate was estimated at $0.8 \mathrm{~cm}$.year ${ }^{-1}$ for the region of the tidal inlet, the origin of the sediments being marine (OFFICER et al., 1984), as evidenced in this study.

LIMA et al. (2011) pointed out that in the last 10 years the Santa Helena dam (Bahia-Brazil) has contributed to the maintenance of the estuary of the Jacuípe river due to artificially released water discharge peaks, with the capacity to erode the sediments and to help unblocking the channel.

The rivers with extensive river basins and considerable rainfall transport a large volume of sediments to their estuaries, filling them quickly. However, for the discharges exceeding 200,000 $\mathrm{m}^{3} . \mathrm{s}^{-1}$ from the Amazon river, it appears that the sediments are currently being released directly into the sea, with little silting at the mouth $\left(0.1 \mathrm{~cm}^{\text {year }}{ }^{-1}\right)$, whereas from the inner continental shelf the rate is of 60 cm.year-1 (DUKAT; KUEHL, 1995). On the outer shelf, the rate is very high, ranging from 5-15 m.year ${ }^{-1}$ (KUEHL et al., 1986). These results demonstrate the importance of 
maintaining the flow of inland water bodies to avoid filling the channels of their estuarine systems.

In the case of the São Luís tidal inlet, no contributions from the Bacanga dam for the excavation of deposited sediment were observed. This can be explained as being due to the decrease of fluvial competence, and hence to the decrease in the flow arising from the artificial discharge. It is also the result of an intense urbanization process that occurred in the area and the irregularity of the opening of the floodgates, along with existing mechanical problems in their structure that prevented their complete opening.

The evaluation of the results showed intense and advanced sedimentary filling processes in the São Luís tidal inlet, at rates proportionately higher than those found in other estuaries, calling for corrective actions and the implementation of coastal management policies for this area. Sedimentation processes have become very common on the Brazilian coast with the consequent loss of several estuarine systems (LESSA, 2006).

The evaluation of the sedimentation dynamics in the São Luís tidal inlet showed that the deposited volume has intensified over 64 years of monitoring.

The analysis of the morphological bottom dynamics from 1947 to 2011 indicated transformations represented mainly by the increase in the number of areas above $0 \mathrm{~m}$ DHN and by morphological changes in navigation channels.

Therefore, with the urban development foreseen for the historical center of São Luís city, the revitalization of tourism, the increase in port activities and the considerable interest in the real estate development of the coastal zone, greater interaction is needed with research institutions for the establishment of land use policies and the rational occupation of land in fragile ecosystems such as estuaries and the coastal zone, organizing or preventing activities near the coast to ensure the stability of the natural balance of such areas.

\section{REFERENCES}

ALBINO, J.; PAIVA, D. S.; MACHADO, G. M. Geomorfologia, tipologia, vulnerabilidade erosiva e ocupação urbana das praias do litoral do Espírito Santo, Brasil. Geografares, v. 2, n. 2, p. 63-69, 2001.

ARAÚJO, M. C. B.; SOUZA, S. T.; CHAGAS, A. C. O.; BARBOSA, S. C. T.; COSTA, M. F. Análise da ocupação urbana das praias de Pernambuco, Brasil. Rev. Gest. Cost. Integ., v. 7, n. 2, p. 97-104, 2007.

BOYD, R.; DALRYMPLE, R. W.; ZAITLIN, B. A. Classification of clastic coastal depositional environments. Sediment. Geol., v. 80, n. $3 / 4,139-150,1992$.
CARVALHO, N. O.; FILIZOLA JÚNIOR, N. P.; SANTOS, P. M. C.; LIMA, J. E. F. W. Guia de avaliação de assoreamento de reservatórios. Brasília: ANEEL, 2000. 140 p.

COWELL, P. J.; THOM, B. G. Morphodynamics of coastal evolution. In: CARTER, R. W. G.; WOODROFFE, C. D. Coastal Evolution, Late Quaternary Shoreline Morphodynamics. Cambridge: Cambridge University Press, 1997. p. 33-86.

DUKAT, D. A.; KUEHL, S. A. Non-steady-state ${ }^{210} \mathrm{~Pb}$ flux and the use of ${ }^{228} \mathrm{Ra} /{ }^{226} \mathrm{Ra}$ as a geochronometer on the Amazon continental shelf. Mar. Geol., v. 125, n. 3/4, p. 329-350, 1995.

FAN, H.; HUANG, H.; ZENG, T. Impacts of anthropogenic activity on the recent evolution of the Huanghe (Yellow) River delta. J. Coastal. Res., v. 22, n. 4, p. 919-929, 2006.

FIGUEIRA, R. C. L.; TESSLER, M. G.; MAHIQUES, M. M.; FUKUMOTO, M. M.; GOYA, S. C. Sedimentação recente e níveis de metais pesados em testemunhos do estuário santista, São Paulo, Brasil. Anais do IV Congresso de Pesquisas Ambientais e Saúde. Santos, 2004. p. 73-76.

FRAGOSO JÚNIOR, C. R.; BUARQUE, D. C.; TUCCI, C. E. M. Uma avaliação integrada do assoreamento e da poluição urbana sobre a qualidade da água na Embocadura Estuarina de São Luís MA. In: II Simpósio de Recursos Hídricos do Sul-Sudeste, 2008, Rio de Janeiro. Anais do II Simpósio de Recursos Hídricos do Sul-Sudeste. Porto Alegre: ABRH, 2008.

JAFFE, B. E.; SMITH, R. E.; FOXGROVER, A. C. Anthropogenic influence on sedimentation and intertidal mudflat change in San Pablo Bay, California: 1856-1983. Estuar. Coast. Shelf Sci., v. 73, n. 1/2, p. 175-187, 2007.

KUEHL S. A.; DEMASTER, D. J.; NITTROUER, C. A. Nature of sediment accumulation on the Amazon continental shelf. Cont. Shelf Res., v. 6, n. 1/2, p. 209-225, 1986.

LANDIM, P. M. B. Introdução aos métodos de estimação espacial para confecção de mapas. Rio Claro: UNESP, 2000. 20 p.

LESSA, G. C. Brazilian coastal bays: large estuaries in a regressive coast. In: ÂNGULO, R.; KLEIN, H.; SOUZA, C. (Eds.). $3^{\text {rd }}$ IGCP 495 Meeting. Balneário Camboriú, Brazil. Proceedings, 2006. p. 1-4.

LIMA, G.M.P., Caracterização Sedimentológica e dos Padrões de Circulação e Mistura do Estuário do Rio Jacuípe - Litoral Norte do Estado da Bahia. Dissertação - INSTITUTO DE GEOCIÊNCIAS (Mestrado em Geologia), Universidade Federal da Bahia, 2007.http://www.pggeologia.ufba. $\mathrm{br} / \mathrm{v} 1 /$ index.php/biblioteca-digital/dissertacoes/marinha-costeira-e-sedimentar-/277-geraldo-marcelo-pereira-lima-2007

LIMA, G. M. P.; VILAS BOAS, G. S.; COSTA, A. B.; ARGOLLO, R. M. Taxas de sedimentação recentes provenientes dos mé-

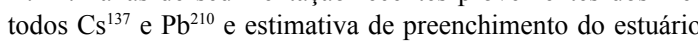
Jacuípe, Bahia, Brasil. Rev. Bras. Geociênc., v. 41, n. 1, p. 44$55,2011$.

LIMA, G. M. P.; LESSA, G. C.; FRANKLIN, T. S. Avaliação dos impactos da barragem de Santa Helena no trecho estuarino do rio Jacuípe, litoral norte da Bahia - Brasil. Quat. Environ. Geosci. v. 02, n. 1, p. 40-54, 2010.

MADRUGA FILHO, J. D. Aspectos geoambientais entre as praias do Paiva e Gaibú, Município do Cabo de Santo Agostinho (Litoral sul de Pernambuco). Tese de Doutorado. UFPE., Centro de Tecnologia e Geociências, 2004. http://repositorio. ufpe.br/bitstream/handle/123456789/6529/arquivo6870 1. pdf? sequence $=1 \&$ isAllowed $=y$ 
MARTÍNEZ, G. M.; PÉREZ-ARLUCEA, M.; GONZÁLEZVILLANUEVA, R.; CAMPOS, A. O. Anthropogenic influence on the Holocene sedimentation process along the Atlantic coast of Galicia (NW Iberian Peninsula). J. Coastal. Res., v. 64, p. 1788-1792, 2011.

ODRESKI, L. L. R.; SOARES, C. R.; ANGULO, R. J.; ZEM, R. C. Taxas de assoreamento e a influência antrópica no controle da sedimentação da Baía de Antonina, Paraná. Bol. Par. Geoc., v. 53, p. 7-12, 2003.

OFFICER, C. B.; LYNCH, D. R.; SETLOCK, G. H.; HELZ, G. R. Recent Sedimentation Rates in Chesapeake Bay. In: KENNEDY, V. S. (Ed.). The Estuary as a Filter. New York: Academic Press, 1984. p. 131-157.

OLIVEIRA, G. H. R.; PATCHINEELAM, T. C. S; PATCHINEELAM, S. M. Validação do método de geocronologia de ${ }^{210} \mathrm{~Pb}$ por espectrometria gama utilizando o detector coaxial de GE ultrapuro do Departamento de Geoquímica da UFF. Anais do II Simpósio Brasileiro de Oceanografia. São Paulo, 2004.
SAITO, R. T.; FIGUEIRA, R. C. L.; TESSLER, M. G.; CUNHA, I. I. L. $210 \mathrm{~Pb}$ and $137 \mathrm{Cs}$ geochronologies in the Cananéia-Iguape estuary (São Paulo, Brazil). J. Radioanal. Nucl. Chem., v. 249, n. 1, p. 257-261, 2001.

SHI, J.; LI, G.; WANG, P. Anthropogenic influences on the tidal prism and water exchanges in Jiaozhou Bay, Qingdao, China. J. Coastal. Res., v. 27, n. 1, p. 57-72, 2011.

SOUZA, C. R. G. Coastal erosion and the coastal zone management challenges in Brazil. J. Integr. Coast. Zone Manage., vl. 9, n. 1, p. 17-37, 2009.

WOODROFFE, C. D. The natural resilience of coastal systems: primary concepts. In: MCFADDEN, L.; PENNING-ROWSELL, E.; NICHOLLS, R. J. (Eds.). Managing Coastal Vulnerability. Amsterdam: Elsevier, 2007. p. 45-60.

WRIGHT, L. D.; THOM, B. G. Coastal depositional landforms: a morphodynamic approach. Prog. Phys. Geog., v. 1, p. 412-459, 1977.

WRIGHT, S. A.; SCHOELLHAMER, D. H. Trends in the sediment yield of the Sacramento River, California, 1957-2001. San Franc. Estuary Watershed Sci., v. 2, n. 2, p. 1-14, 2004. 